\title{
COMPETITIVENESS AND ADAPTABILITY TO THE EUROPEAN MARKET OF THE STOCK BREEDING BRANCH IN STARA ZAGORA DISTRICT
}

\author{
Nadezhda Petrova, Iskra Nencheva \\ Trakia University, Economic Faculty, Department of Management, Stara Zagora, Bulgaria \\ nfp@abv.bg
}

\begin{abstract}
Agriculture and livestock breeding are branches, which determine the economic structure of Stara Zagora district. In the last years the stock breeding in the district has marked progress, and the product quality has been improved and stabilized in quantitative aspect. There are milk and meat processing companies, situated in Stara Zagora district, which work for the European market. The purpose of this paper is to investigate the competitiveness and adaptability to the European market of the stock-breeding branch in Stara Zagora district. In order to achieve this goal, the following tasks have to be solved: - to analyze the condition of the stock-breeding branch in Stara Zagora district; - to examine the trends in the development of the stock-breeding branch; - to analyze the possibilities for sale of the animal products on the European market. The following methods are applied in order to achieve this goal and to solve the tasks such as analysis and synthesis, a systematic approach, a structural approach, statistical methods.
\end{abstract}

Key words: competitiveness; stock breeding; market; quality

\section{КОНКУРЕНТНОСТА И АДАПТАБИЛНОСТА КОН ЕВРОПСКИОТ ПАЗАР НА СТОЧАРСКИТЕ ПРОИЗВОДИ ВО ОБЛАСТА СТАРА ЗАГОРА}

\begin{abstract}
Земјоделството и сточарството се гранки кои ја детерминираат економската структура во областа Стара Загора. Во последните години сточарството во оваа област бележи напредок, како и подобрување на квалитетот на производите и стабилизација од квантитативен аспект. Во Стара Загора постојат компании за преработка на месо и млеко, кои работат за европскиот пазар. Целта на овој труд е да се истражи конкурентноста и адаптабилноста кон европскиот пазар на сточарските производи од областа Стара Загора. За да се постигнат овие цели, треба да се разрешат следните задачи: да се анализира состојбата на сточарството во областа Стара Загора, да се истражат трендовите на развојот на сточарството, да се анализираат можностите за продажба на анимални производи на европскиот пазар. За постигнување на оваа цел и за разрешување на задачите се применети следните методи: анализа и синтеза, систематски пристап, структурен пристап, статистички методи итн.
\end{abstract}

Клучни зборови: конкурентност; сточарство; пазар; квалитет

\section{INTRODUCTION}

Agriculture and livestock breeding are brancheds which determine the economic structure of Stara Zagora district. The reasons in the first place include the favourable geographic location of the district and the beneficial climatic conditions. They foster the cultivation of different cultures which, on the other hand, stimulate the de- velopment of the stock breeding. The rational utilization of these advantages for the general development of Stara Zagora district requires measures to be undertaken for attraction of more investments. The investments are necessary to provide competitiveness of the agricultural branch by enlargement of the farms, by application of modern and more efficient technologies, by purchasing new equipment, by attracting young people to work in the agricultural sector, by construction of 
the necessary market infrastructure and establishment of a state-of-the-art information system.

In the last years the stock breeding in the district has marked progress, and the product quality has been improved and stabilized in quantitative aspect.

There are milk and meat processing companies, situated in Stara Zagora district, which work for the European market.

\section{MATERIAL AND METHOD}

The purpose of this paper is to investigate the competitiveness and adaptability to the European market of the stock-breeding branch in Stara Zagora district.

In order to achieve this goal, the following tasks have to be solved:

- to analyze the condition of the stock-breeding branch in Stara Zagora district;

- to examine the trends in the development of the stock-breeding branch;

- to analyze the possibilities for sale of the animal products on the European market.

The following methods are applied in order to achieve this goal and to solve the tasks such as analysis and synthesis, a systematic approach, a structural approach, statistical methods.

\section{RESULTS AND ANALYSIS}

The administrative district of Stara Zagora is one of the largest in Bulgaria according to its territory. It occupies an area of 5151.1 square $\mathrm{km}$, or $4,6 \%$ of the territory of the country. It is located in the central part of Bulgaria and is a part of the South-central region which includes five more districts with administrative centres: Plovdiv, $\mathrm{Pa}$ zardzhik, Smolyan, Kardzhali and Haskovo.

The population of the district at the end of 2007 was 364051 residents, $31.71 \%$ of whom living in the villages. This index is close to the average for the country since by data of the National Statistical Institute the relative share of the rural population in Bulgaria for the same period was $30.25 \%$.
In administrative aspect the district includes 11 municipalities, in which there are 206 settlements -11 towns and 196 villages.

The agricultural, forestry and fish-breeding branch with all its sub-branches is traditionally strong for the Stara Zagora region. In 2007 the branch has generated a net income by sales to the amount of 141 mllion levs, with 109 mllion levs in the previous year. The total profit of the companies in this branch amounted to 22 mllion levs, with 10 mllion levs more than the previous year. The successful development of the agricultural sector was a result of the existing favourable conditions:

- Rich cultivated land;

- Multiannual tradition in agriculture and valuable human experience;

- Presence of markets - both regional and national, and for certain products - international;

- Favourable position on the republican road infrastructure;

- Possibilities for attraction of financial amounts under the EU structural funds both for production and for processing and storage of agricultural products.

There are good conditions and possibilities on the territory of Stara Zagora district to raise animals of almost all breeds and for product choices which are characteristic for the Bulgarian stock breeding. The main function of the stock breeding branch is connected with the production of milk. About $80 \%$ of the produced quantities of milk are cow milk.

The stock breeding branch in 2007 developed in the conditions of the EU membership of Republic of Bulgaria and the activities of all that are engaged with agri-food products - producers, traders and administrators, was connected with the provision of a steady, market-orientated and environmentally friendly production. The mechanisms and the rules of the Common Agricultural Policy were enforced, the production and processing sectors proceeded with their restructuring and the investment in them continued in order to ensure optimal conditions for production and processing.

The new requirements connected with the production of qualitative and safe animal raw materials evoked enlargement, modernization and restructuring of the animal farms. As a result, a considerable decrease was observed in the number of farms $-10.8 \%$ as well as an increase of the average number of raised animals. 


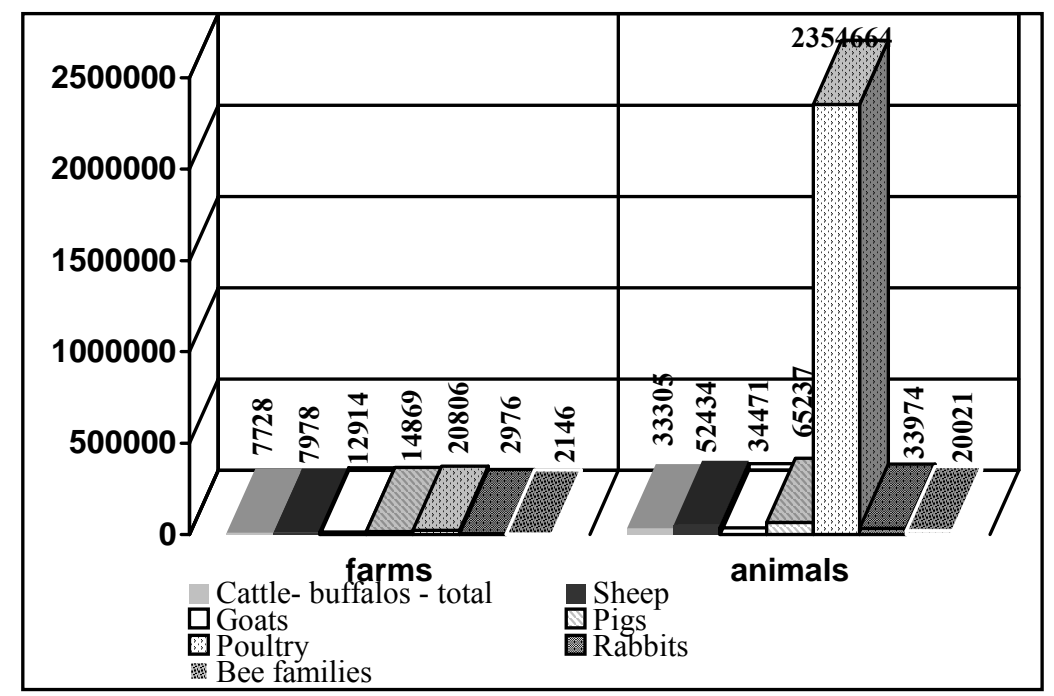

Fig. 1. Structure of the stock-breeding branch in Stara Zagora district

The buffalo breeding in the region is based on the Bulgarian Murrah breed. The animals yield ecologically pure delicacy products which is a precondition for increasing their number.

The tendency for restructuring of the cattlebreeding sector and for optimization of the number of animals in the farms, which started in 2006, continued in 2007 as well. The reform in the dairy sector is basically connected with the introduction of the quota system in 2007 as part of the General organization of agricultural products markets.

The quota system for the cow milk has the aim to stabilize the market in the dairy sector by achieving a balance between demand and supply, by ensuring a better lifestyle for the farmers and enhancement of the competitiveness of the dairy products.

The main share in the sheep-breeding branch is occupied by the special milk breeds. In order to stimulate the meat sheep-breeding, the focus is on the raising of the Ile-de-France and Mouton Charollais breeds.

The pig-breeding depends on the breeds Large White, Landrace and Bulgarian White which are predominant in the pig farms in the district.

The poultry breeding and the production of eggs and chicken meat enlarge their volumes by using the available facilities in industrial poultry farms with a full production cycle.

The relief, the flora and the ecologically pure environment in some municipalities are especially suitable for apiculture. The increased number of the bee families shows that this sub-branch has good prospects ahead. About $90 \%$ of the products are sold abroad and are welcomed on markets in EU countries, in the USA and Canada.

In 2007 the preparation for enforcement of the National Apiculture Program for the period from 2008 to 2010 started, whose goal was to improve the general conditions for production and trade with bee honey and bee products by assisting the agricultural producers. The assistance principle is based on reimbursement of part of the expenses incurred under the envisaged five program actions.

The economics of the Republic of Bulgaria in the first year of its EU membership is characterized by stability and growth of the basic macroeconomic indices. The created gross added value (GAV) among the economic activities in the country in 2007 according to the current prices has marked a growth of $6.3 \%$ in the real expression as compared to GAV created in 2006.

The agrarian sector has registered a diminution of the physical volume of GAV with $29.7 \%$, compared to that of 2006. This drop, in combination with the impressive rates of the GAV growth in the other economic sectors contributes to the confirmation of the tendency from the previous years for decrease of the relative share of the agrarian sector in GAV within the national economics - from $9.4 \%$ in $2005,8.5 \%$ in 2006 up to $6.2 \%$ in 2007 .

The problems, accompanying the course of the agrarian branch in 2007, influenced the foreign trade with agricultural goods which, in contrast to 
the latest years, ended with a negative balance to the amount of 140853 thousand USD.

Table 1

Foreign trade with agricultural goods (million. levs)

\begin{tabular}{lcccc}
\hline \hline & 2004 & 2005 & 2006 & 2007 \\
\hline Foreign trade balance & -4480 & -6926 & -9270 & -12487 \\
$\begin{array}{l}\text { Incl.: ** } \\
\begin{array}{l}\text { Balance of the trade } \\
\text { with agricultural goods }\end{array}\end{array}$ & $+389,0$ & $+545,7$ & $+310,0$ & $-201,3$ \\
\hline \hline
\end{tabular}

On the grounds of the performed study, the following possibilities for enhancement of the competitiveness of the stock-breeding branch can be pointed out:

- To create conditions for enlargement, modernization and technological renovation of the animal farms.

- To increase the average animal yield by assisting the work of the organizations occupied with selection and reproduction.

- To introduce and enforce the rules for the good practices concerning farm animal raising.
- To improve the control for adherence to the zoo-hygienic and veterinary medical requirements, for quality and hygiene of the products, for environmental protection.

- Completion and enforcement of statutory regulations connected with the application of the Total Agricultural Practice.

\section{REFERENCES}

[1] Ivanov, B. et al. (2008): Trends in the development of the stock-breeding branch during the period of the European integration, Economics and Management of Agriculture, 53 (3).

[2] Popov, R., B. Ivanov (2009): Effect of the application of the EU Common Agricultural Policy on Agriculture and the Rural Regions, Economics and Management of Agriculture, 54 (3).

[3] Slavova, Y. A., et al. (2006): Competitiveness of the agrarian products on the home and international markets, IAI.

[4] Slavova, Y. A. (2005): The import of agrarian products - a major indicator for the competitiveness of the Bulgarian agriculture, IAI.

[5] Slavova, Y. A. et al. (2008): The Bulgarian agriculture challenges, problems and trends in the development in the conditions of the Common Agricultural Policy, Economics and Management of Agriculture, 53 (3).

[6] Agrarian Report of the Ministry of Health and Foods, 2005-2008.

[7] National Statistical Year-Book, 2005-2008. 